\title{
ANALISA DAYA SAING RUMPUT LAUT DI INDONESIA (STUDI KASUS: KABUPATEN KONAWE SELATAN, SULAWESI TENGGARA)
}

\author{
Estu Sri Luhur, Cornelia Mirwantini Witomo dan Maulana Firdaus \\ Balai Besar Penelitian Sosial Ekonomi Kelautan dan Perikanan \\ JI. KS. Tubun Petamburan VI Jakarta 10260 \\ Telp. (021) 53650162, Fax. (021) 53650159 \\ Diterima 29 Februari 2012 - Disetujui 4 Juni 2012
}

\begin{abstract}
ABSTRAK
Penelitian ini bertujuan untuk menganalisis daya saing budidaya rumput laut di Kabupaten Konawe Selatan, Sulawesi Tenggara dan telah dilakukan pada bulan September 2011. Metode analisis penelitian ini menggunakan Policy Analysis Matrix (PAM), dengan menggunakan data rumput laut dari Kabupaten Lombok Timur untuk memperoleh nilai ekonomi (harga sosial). Nilai Domestic Resource Cost Ratio (DRCR) sebesar 0,98 menunjukkan bahwa usaha rumput laut di Kabupaten Konawe Selatan memiliki keunggulan komparatif dan daya saing lebih besar dibandingkan dengan usaha rumput laut di Kabupaten Lombok Timur. Sebaliknya, nilai Tradable Resource Cost Ratio (TRCR) sebesar 1,38 menunjukan kurang mampu bersaing dengan usaha budidaya rumput laut di Kabupaten Lombok Timur. Peningkatan daya saing rumput laut di Kabupaten Konawe Selatan dapat dilakukan melalui kebijakan penurunan harga satuan bibit dan bahan bakar minyak (BBM) secara bersama-sama sebesar $28 \%$ serta kebijakan peningkatan harga satuan tenaga kerja upahan dan depresiasi aset produksi secara keseluruhan sebesar $4 \%$.
\end{abstract}

Kata kunci: daya saing, rumput laut, Policy Analysis Matrix (PAM)

\section{Abstract : Competitiveness of Seaweed Commodity in Indonesia (Case Study: South Konawe Regent, South-East Sulawesi). By : Estu Sri Luhur, Cornelia Mirwantini Witomo and Maulana Firdaus.}

The study aims to analyze the competitiveness of seaweed farming South Konawe regency, SouthEast Sulawesi was conducted in September 2011. Analysis methods of this research using the Policy Analysis Matrix (PAM) using economic value (social prices) data which is collect from the east Lombok seaweed. The value of Domestic Resource Cost Ratio (DRCR) (0.98) indicates that the seaweed business in South Konawe has a comparative advantage and more competitive than the seaweed in East Lombok. Contrarily, based on Tradable Resource Cost Ratio (TRCR) values (1.38) is less able to compete with the cultivation of seaweeds in East Lombok. The seaweed of South Konawe competitiveness should be improve by policy implementation of lowering the unit cost of seed and fuel oil (BBM) jointly by $28 \%$ and increase the unit cost of hired labor and depreciation of assets overall production by $4 \%$.

Keywords: competitiveness, seaweed, Policy Analysis Matrix (PAM) 


\section{PENDAHULUAN}

Indonesia sebagai negara kepulauan memiliki potensi areal budidaya rumput laut seluas 1,2 juta Ha dengan potensi produksi rumput laut kering rata-rata 16 ton per $\mathrm{Ha}$. Apabila seluruh lahan dapat dimanfaatkan maka produksi rumput laut diperkirakan akan mencapai 17.774.400 ton per tahun dengan harga $\mathrm{Rp} \mathrm{4,5}$ juta per ton (DKP, 2008). Oleh karena itu, pemerintah melalui Kementerian Kelautan dan Perikanan menetapkan rumput laut sebagai salah satu komoditas unggulan dalam program revitalisasi perikanan melalui program minapolitan.

Dewasa ini budidaya rumput laut (seaweed culture), terutama budidaya rumput laut jenis Eucheuma cottonii berkembang pesat. Fungsi rumput laut sebagai bahan baku berbagai produk olahan bernilai ekonomi tinggi untuk tujuan pangan maupun non pangan yang membuat rumput laut banyak dibudidayakan dan diperdagangkan di pasar lokal dan internasional. Karaginan sebagai hasil olahan rumput laut selanjutnya diolah lagi menjadi bahan makanan dan minuman, pet-food, bahan baku industri farmasi, serta kosmetik. Selain itu, rumput laut dapat juga diproses menjadi bahan emulsi, pembentuk gel, bahan film dan pembentuk busa pada sabun (Bank Indonesia, 2009). Bahkan, hasil penelitian para ilmuwan Bio Architecture Lab Inc (BAL) di Berkeley menunjukkan bahwa rumput laut bisa diolah menjadi bahan bakar bioetanol dengan bantuan bakteri E. coli (Tempo, 2012).

Beragamnya industri yang memanfaatkan rumput laut sebagai bahan baku produksinya membuat permintaan atau kebutuhan rumput laut di pasar dalam dan luar negeri diperkirakan meningkat. Pada tahun 2010, kebutuhan rumput laut sebagai bahan baku industri pengolahan di dalam negeri 34.440 ton kering, sedangkan total ekspor mencapai 106.200 ton kering. Dengan jumlah produksi rumput laut penghasil karagenan adalah 140.020 ton kering maka sebanyak $75,85 \%$ produksi rumput laut Indonesia dipasarkan ke luar negeri (Kompas, 2011).
Hasil penelitian Anggadiredja et al. (2006) memperkirakan pasar dunia produk olahan rumput laut meningkat sekitar $10 \%$ per tahun untuk karaginan semirefine (SRC), agar, dan alginat untuk industri, sedangkan pasar alginat untuk makanan meningkat 7,5\% dan karaginan refine meningkat sekitar $5 \%$. Anggadiredja juga memprediksi permintaan dunia terhadap rumput laut kering penghasil karagenan pada tahun 2012 mencapai 369.800 ton atau naik dua kali lipat jika dibandingkan dengan kebutuhan tahun 2007 (Kompas, 2011).

Tingginya permintaan rumput laut tersebut mendorong para pembudidaya rumput laut untuk meningkatkan produksinya. Berdasarkan data KKP (2011), produksi rumput laut Indonesia sejak tahun 2007-2010 meningkat rata-rata 30,57\% per tahun dan meningkat $32,11 \%$ dalam kurun waktu 2009-2010. Tercatat pada tahun 2007, produksi rumput laut Indonesia mencapai 1,7 juta ton dan terus meningkat menjadi 2,9 juta ton pada tahun 2009 dan 3,9 juta ton pada tahun 2010 .

Peningkatan produksi rumput laut dalam negeri cenderung tidak diikuti oleh permintaan ekspor rumput laut Indonesia ke negara-negara tujuan. Tercatat bahwa volume ekspor rumput laut menunjukkan trend menurun dari tahun 2007 hingga 2009. Permintaan ekspor rumput laut Indonesia menurun dari 94,07 juta $\mathrm{kg}$ pada tahun 2007 menjadi 47,25 juta kg pada tahun 2008 dan 39,82 juta kg di tahun 2009 atau turun $33 \%$ per tahun (KKP, 2010). Menurut Husodo dalam Hasibuan (2008), penurunan ekspor ini menjadi salah satu indikator rendahnya daya saing suatu produk sehingga daya saing rumput laut Indonesia dapat dikatakan rendah dibandingkan negara-negara penghasil rumput laut di dunia.

Hasil penelitian Rajagukguk (2009) menunjukkan bahwa posisi daya saing ekspor rumput laut Indonesia cenderung tinggi pada negara Hong Kong, Filipina, Spanyol, dan Denmark karena pangsa pasarnya lebih dari $20 \%$. Indonesia disimpulkan tidak memiliki daya saing sama sekali di negara Jepang, Inggris 
(United Kingdom), dan Perancis karena pangsa pasar Indonesia di ketiga negara tersebut tidak lebih dari $20 \%$.

Menurut Hasibuan dan Bedy (2008), rendahnya daya saing rumput laut disebabkan oleh faktor eksternal dan faktor domestik. Faktor eksternal ditunjukkan oleh adanya peningkatan persaingan dengan Cina sebagai penghasil utama rumput laut di pasar internasional. Faktor domestik ditunjukkan oleh tidak meratanya tingkat daya saing yang dimiliki oleh setiap daerah sentra produksi rumput laut. Untuk itu, penelitian ini bertujuan untuk mengkaji daya saing komoditas rumput laut di Kabupaten Konawe Selatan, Sulawesi Tenggara dibandingkan dengan usaha budidaya rumput laut di Kabupaten Lombok Timur, Nusa Tenggara Barat.

\section{METODOLOGI}

\section{Lokasi dan Waktu Penelitian}

Penelitian dilaksanakan pada bulan September 2011 di Kabupaten Konawe Selatan, Sulawesi Tenggara. Lokasi ini dipilih dengan dasar alasan karena Provinsi Sulawesi Tenggara merupakan salah satu wilayah penghasil utama rumput laut di Indonesia dengan Konawe Selatan sebagai sentra produksinya.

\section{Pengumpulan dan Analisis Data}

Data yang digunakan mencakup data sekunder dan primer. Data sekunder dikumpulkan dengan cara mencatat dan mempelajari dokumen tertulis berupa laporan. Data ini dikoleksi dari berbagai lembaga atau dinas, yaitu Pusdatin Kementerian Kelautan dan Perikanan, Biro Pusat Statistik Kabupaten, dan dinas terkait. Data sekunder yang digunakan adalah produksi rumput laut Indonesia, volume ekspor rumput laut, hasil-hasil penelitian terdahulu, dan data statistik dari FAO.

Data primer diperoleh melalui survei dan wawancara kepada pembudidaya rumput laut, pengolah produk perikanan, tokoh masyarakat, serta dinas-dinas yang terkait seperti dinas Kelautan dan Perikanan. Data primer yang digunakan terkait usaha budidaya rumput laut meliputi jumlah produksi, harga jual rumput laut, biaya variabel, biaya tetap, investasi usaha, saluran pemasaran rumput laut dari pembudidaya hingga pedagang besar, dan margin usaha yang diperoleh di setiap tingkat pedagang. Data primer tersebut dikumpulkan dengan menggunakan kuesioner sebagai panduan dalam menggali informasi dari responden.

Data primer dikumpulkan dari dua lokasi, yaitu lokasi Kabupaten Konawe Selatan sebagai lokasi penelitian dan Kabupaten Lombok Timur sebagai daerah pembanding untuk melihat daya saing rumput laut di Sulawesi Tenggara. Lokasi Kabupaten Lombok Timur, Nusa Tenggara Barat (NTB) dipilih sebagai wilayah pembanding karena teknik budidaya dan spesies rumput laut yang digunakan sama dengan usaha budidaya rumput laut di Kabupaten Konawe Selatan. Selain itu, wilayah Lombok Timur, Nusa Tenggara Barat, merupakan salah satu lokasi pengembangan rumput laut sejak tahun 1960-an (Bank Indonesia, 2009).

Data yang dikumpulkan kemudian dianalisis dengan menggunakan pendekatan Policy Analysis Matrix (PAM) untuk mengkaji tingkat daya saing rumput laut. Daya saing suatu komoditas sering diukur dengan menggunakan pendekatan keunggulan komparatif dan kompetitif. Keunggulan komparatif merupakan suatu konsep yang dikembangkan oleh David Ricardo untuk menjelaskan efisiensi alokasi sumber daya yang terbuka (Koo dan Kennedy, 2005). Keunggulan komparatif suatu produk sering dianalisis dengan pendekatan Domestic Resource Cost Ratio (DRCR). Menurut Monke dan Pearson (1989), guna memperoleh nilai DRCR maka analisis yang digunakan adalah Policy Analysis Matrix (Tabel 1). Input tradable adalah input yang dapat diperdagangkan di pasar internasional, sedangkan input nontradable atau disebut juga faktor domestik merupakan input yang tidak diperdagangkan di pasar internasional.

Secara sederhana, sebuah matriks analisis kebijakan (PAM) tersusun dari empat buah kolom yang mewakili parameter penerimaan, biaya input tradable, biaya faktor 
domestik dan profit; serta tiga baris yang terdiri dari nilai finansial, nilai ekonomi dan divergensi dari parameter-parameter yang terdapat pada kolom, seperti yang terlihat pada Tabel 1. Pada matriks tersebut terdapat dua buah hasil perhitungan berupa identitas; yang pertama adalah sebuah kolom yang menunjukkan besarnya profitabilitas yang merupakan perbedaan antara penerimaan dan total biaya; dan kedua adalah sebuah baris yang mengukur dampak dari adanya divergensi (akibat dari adanya kebijakan dan kegagalan pasar) yang menunjukan perbedaan antara nilai finansial dan nilai sosial. Idealnya apabila tidak terjadi kegagalan pasar dan kebijakan yang mengakibatkan distorsi maka tidak terjadi perbedaan antara nilai finansial dan nilai sosial (divergensi) sehingga nilai- nilai parameter pada baris divergensi akan bernilai nol.

Hasil perhitungan biaya dan penerimaan privat maupun sosial dirinci menurut barang tradable dan nontradable yang selanjutnya disusun dalam satu matriks PAM. Dari model PAM tersebut kemudian dihitung nilai Domestic Resource Cost Ratio (DRCR) dimana nilai DRCR $<1$ menunjukkan bahwa usaha budidaya rumput laut di Kendari dan Konawe Selatan lebih menguntungkan dibanding usaha budidaya rumput laut di Lombok Timur dan begitupula sebaliknya. Selain DRCR, analisis lainnya yang bisa diturunkan dari PAM adalah tradable resource cost ratio (TRCR) dan total cost ratio (TCR).

Tabel 1. Formulasi Policy Analysis Matrix (PAM).

Table 1. Formulation of Policy Analysis Matrix (PAM).

\begin{tabular}{lllll}
\hline \multirow{2}{*}{ Uraian/Descriptions } & Penerimaan/ & Biaya/Costs & Keuntungan/ \\
\cline { 3 - 4 } & Revenues & $\begin{array}{c}\text { Input Tradable/ } \\
\text { Tradable Inputs }\end{array}$ & $\begin{array}{c}\text { Faktor Domestik/ } \\
\text { Domestic Factors }\end{array}$ & Profits \\
\hline
\end{tabular}

Nilai Finansial (harga privat)/ Valued at private prices

A

B

C

$\mathrm{D}^{a}$

Nilai Ekonomi (harga sosial)/

Valued at social prices

E F

$\mathrm{H}^{b}$

Divergensi/Divergences

$\mathrm{I}^{c} \quad \mathrm{~J}^{d}$

$\mathbf{L}^{f}$

Sumber/Source: Monke and Pearson (1989)

Catatan/Notes: ${ }^{a}$ Private Profit, $\mathrm{D}=(\mathrm{A}-\mathrm{B}-\mathrm{C})$

${ }^{b}$ Social Profit, $\mathrm{H}=(\mathrm{E}-\mathrm{F}-\mathrm{G})$

${ }^{c}$ Output Transfers, I = (A - E)

${ }^{d}$ Input Transfers, $\mathrm{J}=(\mathrm{B}-\mathrm{F})$

${ }^{e}$ Factor Domestic Transfers, $\mathrm{K}=(\mathrm{C}-\mathrm{G})$

${ }^{f}$ Net Policy Transfers, $\mathrm{L}=(\mathrm{D}-\mathrm{H})=(\mathrm{I}-\mathrm{J}-\mathrm{K})$

Keterangan/Descriptions:

$A=$ Penerimaan individu, yaitu produksi dikalikan harga pasar (Rp)/ Individual revenue, which is market price multiplied by production (IDR)

$\mathrm{B}=$ Input tradable dikalikan dengan harga pasar (Rp)/Tradable inputs multilpied by market price (IDR)

$\mathrm{C}=$ Input faktor domestik dikalikan harga pasar (Rp)/Domestic factor inputs multiplied by market price (IDR)

$\mathrm{D}=$ Pendapatan individu (Rp)/Individual income (IDR)

$\mathrm{E} \quad=$ Penerimaan sosial, yaitu produksi dikalikan dengan harga sosial (Rp)/Social revenue, which is production multiplied by social price (IDR)

$\mathrm{F}=$ Input tradable dikalikan harga sosial (Rp)/Tradable input multiplied by social price (IDR)

$\mathrm{G}=$ Input faktor domestik dikalikan harga sosial (Rp)/Domestic factor inputs multiplied by social price (IDR)

$\mathrm{H}=$ Pendapatan sosial (Rp)/Social income (IDR) 


\section{HASIL DAN PEMBAHASAN}

\section{Perkembangan Produksi Rumput Laut}

Potensi perikanan yang dimiliki oleh masing-masing wilayah dengan komoditas unggulan yang dimiliki menjadikan persaingan pada produk perikanan. Persaingan antar pedagang membuat pasar semakin terbuka. Oleh karena itu, daya saing suatu produk suatu wilayah menjadi penting untuk melihat kemampuan bersaing dan bertahan untuk memenuhi permintaan pasar.

Komoditas rumput laut yang menjadi salah satu komoditas unggulan dalam program minapolitan menyebabkan berkembangnya usaha budidaya rumput laut. Di Indonesia terdapat beberapa sentra produksi rumput laut, salah satunya adalah Kabupaten Konawe Selatan yang menjadi sentra produksi rumput laut bagi Provinsi Sulawesi Tenggara dengan potensi areal budidaya rumput laut seluas 17.718 hektar. Potensi areal budidaya rumput laut tersebar di delapan kecamatan, yaitu Kecamatan Tinanggea, Pallangga Selatan, Laeya, Lainea, Moramo, Moramo Utara, Kolono, dan Kecamatan Laonti. Potensi terbesar terdapat di Kecamatan Laonti (5.730 ha), Tinanggea (4.892 ha) dan Kecamatan Kolono (2.203 ha).

Wilayah yang juga menjadikan rumput laut sebagai komoditi unggulan selain sapi dan jagung adalah Kabupaten Lombok Timur, Nusa Tenggara Barat. Potensi areal budidaya yang dimiliki seluas 2.000 hektar yang tersebar di empat kecamatannya, yaitu Kecamatan Jerowaru, Keruak, Pringgabaya, dan Kecamatan Sambelia. Kecamatan Jerowaru tercatat sebagai wilayah dengan potensi terbesar (1.808 ha)dengan luas pemanfaatan areal budidaya sebesar $12,81 \%$. Sementara Kecamatan Keruak belum memanfaatkan sama sekali potensi yang ada, sedangkan pemanfaatan lahan di Kecamatan Pringgabaya dan Sambelia relatif kecil yang masing-masing sebesar 0,96\% dan 0,71\% (Dinas Kelautan dan Perikanan Kabupaten Lombok Timur, 2010).
Berdasarkan Tabel 2, areal budidaya rumput laut yang dimanfaatkan di Kabupaten Konawe Selatan dan Kabupaten Lombok Timur relatif rendah. Pemanfaatan areal budidaya di Kabupaten Konawe Selatan baru seluas 2.627 hektar atau sebesar 14,83 $\%$. Kondisi yang sama juga ditunjukkan oleh Kabupaten Lombok Timur yang baru memanfaatkan areal budidayanya seluas 289,6 hektar. Hal ini menunjukkan bahwa meskipun potensi areal budidaya yang dimiliki tidak seluas Kabupaten Konawe Selatan, namun presentase pemanfaatan areal tidak jauh berbeda yaitu sebesar $14,48 \%$.Perkembangan produksi rumput laut Kabupaten Konawe Selatan dan Lombok Timur dalam 2-3 tahun terakhir ditunjukkan oleh Gambar 1.

Berdasarkan data dari Dinas Kelautan dan Perikanan Kabupaten Konawe Selatan (2010), pertumbuhan produksi rumput laut kering memiliki trend meningkat dalam kurun waktu tiga tahun terakhir. Produksi rumput laut pada tahun 2008 tercatat $11.742 \mathrm{~kg}$ yang terus meningkat menjadi $14.904 \mathrm{~kg}$ pada tahun 2009 dan $19.375 \mathrm{~kg}$ pada tahun 2010 atau rata-rata meningkat $28,5 \%$ per tahun. Pola yang sama juga terjadi pada produksi rumput laut kering Kabupaten Lombok Timur. Dalam periode tahun 2009-2010, produksi meningkat dari $6.047 \mathrm{~kg}$ menjadi $9.307 \mathrm{~kg}$ atau tumbuh sebesar $54 \%$.

\section{Struktur Investasi dan Biaya Penerimaan Usaha Budidaya Rumput Laut}

Struktur investasi untuk usaha budidaya rumput laut Cottoni dengan metode longline di Kabupaten Konawe Selatan terdiri dari aset produksi dan biaya operasional per siklus yang ditampilkan pada Tabel 2. Berdasarkan Tabel 2, total investasi yang dikeluarkan untuk satu siklus dengan luas lahan $50 \mathrm{~m} \times 50 \mathrm{~m}$ sebesar $\mathrm{Rp}$ 11.160.150 dengan proporsi Rp 6.580.000 (59\%) untuk aset produksi dan Rp 4.580.150 untuk biaya operasional. 


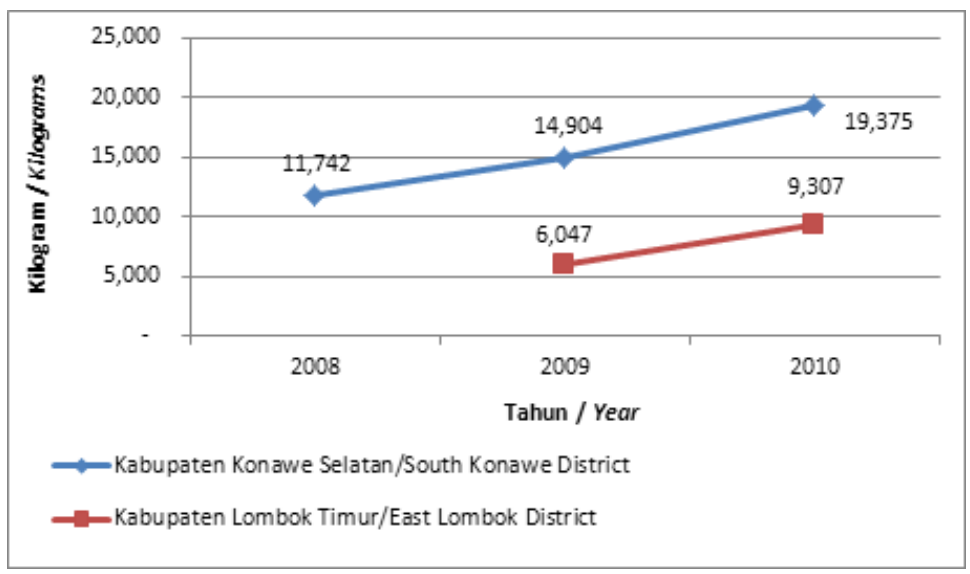

Gambar 1. Perkembangan Produksi Rumput Laut di Kabupaten Konawe Selatan dan Kabupaten Lombok Timur.

Figure 1. Growth of Seaweed Production in South Konawe and East Lombok Regencies.

Sumber: Kabupaten Lombok Timur (2010) \& Statistik Perikanan Budidaya (2011)

Source: Local Authority in Marine and Fisheries service of South Konawe and East Lombok District (2010) \& Aquaculture Statistics (2011)

Tabel 2. Potensi dan Pemanfaatan Areal Budidaya Rumput Laut di Kabupaten Konawe Selatan dan Kabupaten Lombok Timur, 2010.

Table 2. Potency and Utilization of Seaweed Areas in South Konawe and East Lombok Regencies, 2010.

\begin{tabular}{clccc}
\hline $\begin{array}{c}\text { Nomor/ } \\
\text { Number }\end{array}$ & Kabupaten/Regency & $\begin{array}{c}\text { Potensi }(\mathrm{Ha}) / \\
\text { Potency }(\mathrm{Ha})\end{array}$ & $\begin{array}{c}\text { Pemanfaatan }(\mathrm{Ha}) / \\
\text { Utilization }(\mathrm{Ha})\end{array}$ & (\%) \\
\hline 1. & $\begin{array}{l}\text { Konawe Selatan/ } \\
\text { South Konawe }\end{array}$ & 17,718 & 2,627 & 14.83 \\
2. & $\begin{array}{l}\text { Lombok Timur/ } \\
\text { East Lombok }\end{array}$ & 2,000 & 289.6 & 14.48 \\
\hline
\end{tabular}

Sumber: Dinas Kelautan dan Perikanan Kabupaten Konawe Selatan (2010) \&

Dinas Kelautan dan Perikanan Kabupaten Lombok Timur (2010)

Source: Marine and Fisheries Service of the Regency of South Konawe District (2010) \&

Marine and Fisheries Service of the Regency of East Lombok (2010)

Berdasarkan hasil wawancara, strategi yang digunakan untuk memulai usaha budidaya rumput laut $E$. cottoni metode longline adalah: (1) Membeli semua tali yang dibutuhkan terlebih dahulu karena aset produksi yang paling banyak mengeluarkan biaya adalah tali dengan berbagai macam ukuran; (2) Aset produksi yang selanjutnya perlu disiapkan adalah patok kayu, pelampung botol, pelampung gabus serta bibit. Jumlah bibit yang digunakan pada awal usaha budidaya rumput laut tidak perlu sesuai dengan kebutuhan luas lahan karena setelah pemeliharaan 30 hari rumput laut tersebut dapat digunakan lagi sebagai bibit sesuai dengan luas lahan yang dimiliki (Tabel 3).

Usaha budidaya rumput laut di Kabupaten Lombok Timur juga menggunakan jenis rumput laut $E$. Cottoni metode longline seperti di Kabupaten Konawe Selatan. Dengan luasan lahan dan masa pemeliharaan yang sama, struktur investasi untuk usaha budidaya rumput laut di Kabupaten Lombok Timur disajikan pada Tabel 4. 
Tabel 3. Struktur Investasi Usaha Budidaya Rumput Laut Eucheuma cottonii Metode Longline di Kabupaten Konawe Selatan.

Table 3. Investment Structure of Eucheuma cottonii Seaweed with Longline Method in the Regency of South Konawe.

Unit: Satu Siklus (Luasan 50x50 m)/Unit: One Cycle (Area 50x50 m)

\begin{tabular}{lrrr}
\hline \multicolumn{1}{c}{$\begin{array}{c}\text { Struktur Investasi/ } \\
\text { Investment Structure }\end{array}$} & $\begin{array}{c}\text { Jumlah (Unit)/ } \\
\text { Volume (Unit) }\end{array}$ & $\begin{array}{c}\text { Nilai (Rp) } \\
\text { Value (IDR) }\end{array}$ & $\begin{array}{r}\text { Total (Rp)/ } \\
\text { Total (IDR) }\end{array}$ \\
\hline Aset Produksi/Production Assets & 7 & 32,000 & 224,000 \\
Tali No 10/Rope Number 10 & 14 & 32,000 & 448,000 \\
Tali No 8/Rope Number 8 & 39 & 32,000 & $1,248,000$ \\
Tali No 5/ Rope Number 5 & 16 & 35,000 & 560,000 \\
Tali No 1/ Rope Number 1 & 1 & $1,500,000$ & $1,500,000$ \\
Perahu/Boat & 1,150 & 500 & 575,000 \\
Pelampung Botol/Bottle Float & 24 & 70,000 & $1,680,000$ \\
Pelampung Gabus/Cork Float & 30 & 11,500 & 345,000 \\
Patok Kayu/Wooden Poles & & & $\mathbf{6 , 5 8 0 , 0 0 0}$ \\
Total Aset Produksi/ & & & $4,580,150$ \\
Total of Production Assets & & & $\mathbf{1 1 , 1 6 0 , 1 5 0}$ \\
Biaya Operasional Per siklus/ & & & \\
Operation Cost per Cycle & & & \\
\hline Total Investasi/Total Investment & & & \\
\hline
\end{tabular}

Sumber: Data Primer (2011)/Source: Primary Data (2011)

Tabel 4. Struktur Investasi Usaha Budidaya Rumput Laut Eucheuma cottonii Metode Longline Kabupaten Lombok Timur.

Table 4. Investment Structure of Eucheuma cottonii Seaweed with Longline Method in the Regency of East Lombok.

Unit: Satu Siklus (Luasan 50x50 m)/Unit: One Cycle (Area 50x50 m)

\begin{tabular}{|c|c|c|c|}
\hline $\begin{array}{l}\text { Struktur Investasi/ } \\
\text { Investment Structure }\end{array}$ & $\begin{array}{l}\text { Jumlah (Unit)/ } \\
\text { Volume (Unit) }\end{array}$ & $\begin{array}{l}\text { Nilai (Rp)/ Value } \\
\text { (IDR) }\end{array}$ & $\begin{array}{l}\text { Total (Rp)/ Total } \\
\text { (IDR) }\end{array}$ \\
\hline \multicolumn{4}{|l|}{ Aset Produksi/Production Assets: } \\
\hline Tali Nilon 3 mm/3 mm Nylon Rope & 3 & 32,000 & 96,000 \\
\hline Tali Nilon 4 mm/4 mm Nylon Rope & 16 & 32,000 & 512,000 \\
\hline Tali Nilon 10 mm/10 mm Nylon Rope & 22 & 32,000 & 704,000 \\
\hline Tali Nilon 12 mm/12 mm Nylon Rope & 15 & 32,000 & 480,000 \\
\hline Talli rafia/Plastic Rope & 3 & 18,000 & 54,000 \\
\hline Pelampung Ris/Ris Float & 325 & 300 & 97,500 \\
\hline Pelampung Utama/Main Float & 10 & 75,000 & 750,000 \\
\hline Pemberat/Ballast & 16 & 50,000 & 800,000 \\
\hline Terpal $(5 \times 6 \mathrm{~m}) /$ Sheeting $(5 \times 6 \mathrm{~m})$ & 30 & 7,000 & 210,000 \\
\hline $\begin{array}{l}\text { Tenaga Kerja Persiapan Lahan/ } \\
\text { Labour Tillage }\end{array}$ & 1 & 250,000 & 250,000 \\
\hline $\begin{array}{l}\text { Total Aset Produksi/ } \\
\text { Total of Production Assets }\end{array}$ & & & $3,953,500$ \\
\hline $\begin{array}{l}\text { Biaya Operasional Per siklus/ } \\
\text { Operation Cost per Cycle }\end{array}$ & & & $1,323,333$ \\
\hline Total Investasi/Total Investment & & & $5,276,833$ \\
\hline
\end{tabular}

Sumber: Data Primer (2011)/Source: Primary Data (2011) 
Tabel 4 menunjukkan bahwa besarnya total investasi yang dikeluarkan adalah Rp 5.276.833, dengan proporsi aset produksi dan biaya operasional yang dikeluarkan untuk satu siklus masing-masing sebesar Rp 3.953.500 (75\%) dan Rp 1.323.333.

Struktur biaya penerimaan usaha budidaya rumput laut terdiri dari biaya tidak tetap dan biaya tetap. Biaya tidak tetap terdiri dari bibit, tenaga kerja dan biaya pemeliharan aset, sedangkan biaya tetapnya meliputi biaya penyusutan aset atau depresiasi. Struktur biaya penerimaan usaha budidaya rumput laut untuk luasan $50 \mathrm{~m} \times 50 \mathrm{~m}$ per siklus budidaya di Kabupaten Konawe Selatan dan Kabupaten Lombok Timur ditampilkan pada Tabel 5.

Berdasarkan Tabel 5, kegiatan usaha budidaya rumput laut membawa dampak positif bagi perekonomian rumah tangga pembudidaya di pesisir Kabupaten Konawe Selatan dan Kabupaten Lombok Timur. Hasil penelitian menunjukkan bahwa budidaya rumput laut dapat menghasilkan keuntungan bersih bagi pembudidaya di Kabupaten Konawe Selatan dan Kabupaten Lombok Timur masing-masing sebesar Rp 1.882.050/unit dan Rp 3.837.333/unit.

Dilihat dari rasio biaya dan penerimaan ( $R / C$ ratio), usaha budidaya rumput laut di Kabupaten Konawe Selatan dan Kabupaten Lombok Timur masih menguntungkan bagi pembudidaya. Tabel 5 menunjukkan bahwa perhitungan $\mathrm{R} / \mathrm{C}$ ratio mencapai di atas angka 1 , yaitu tepatnya 1,4 untuk usaha budidaya rumput laut di Kabupaten Konawe Selatan dan Kabupaten Lombok Timur. Hal ini mengindikasikan bahwa usaha budidaya rumput laut ini menguntungkan bagi pembudidaya dan layak untuk dikembangkan.

\section{Analisis Daya Saing Komoditas Rumput Laut}

Untuk mengukur daya saing produk rumput laut diukur dengan menggunakan matriks analisis kebijakan atau matriks PAM yang disusun berdasarkan biaya faktor produksi, biaya tradables input dan harga

Tabel 5. Struktur Biaya Penerimaan Usaha Budidaya Rumput Laut Eucheuma cottonii Metode Longline di Kabupaten Konawe Selatan dan Kabupaten Lombok Timur.

Table 5. Revenue Cost Structure of Eucheuma cottonii Seaweed Farming with Longline Method in the South Konawe and East Lombok Regencies.

Unit: Satu Siklus (Luasan 50x50 m)/Unit: One Cycle (Area $50 \times 50$ m)

\begin{tabular}{lcc}
\multicolumn{1}{c}{$\begin{array}{c}\text { Struktur Biaya Penerimaan/ } \\
\text { Revenue Cost Structure }\end{array}$} & $\begin{array}{c}\text { Kabupaten Konawe } \\
\text { Selatan/ South } \\
\text { Konawe Regency }\end{array}$ & $\begin{array}{c}\text { Kabupaten Lombok } \\
\text { Timur/ East Lombok } \\
\text { Regency }\end{array}$ \\
\hline $\begin{array}{l}\text { Biaya Tetap Rp)/Fixed Cost (IDR) } \\
\text { - Depresiasi (Rp)/ } \\
\quad \text { Depreciation (IDR) }\end{array}$ & 440,800 & $1,046,000$ \\
Biaya Tidak Tetap (Rp)/ Variable Cost (IDR) & 440,800 & $1,046,000$ \\
- Bibit (Rp)/Seed (IDR) & $4,580,150$ & $7,616,667$ \\
- BBM (Rp)/Fuel (IDR) & $3,722,150$ & $5,250,000$ \\
- Tenaga Kerja (Rp)/Labour (IDR) & 225,000 & - \\
Total Biaya (Rp)/Total Cost (IDR) & 615,000 & $2,366,667$ \\
Penerimaan (Rp)/Revenue (IDR) & $5,002,950$ & $8,662,667$ \\
\hline Rasio Biaya Penerimaan/ R/C Ratio & $6,885,000$ & $12,500,000$ \\
\hline
\end{tabular}

Sumber: Data Primer (2011)/Source: Primary Data (2011) 
output rumput laut. Berikut matriks PAM Usaha Budidaya Rumput Laut di Kota Kendari serta Kabupaten Konawe Selatan dengan Kabupaten Lombok Timur tahun 2011.

Tabel 6 menunjukkan penerimaan, biaya input produksi, biaya faktor produksi, dan keuntungan bagi pembudidaya rumput laut di Kabupaten Konawe Selatan yang dibandingkan dengan Kabupaten Lombok Timur sebagai salah satu sentra produksi rumput laut di Nusa Tenggara Barat. Dari faktor penerimaan, usaha budidaya rumput laut di Kabupaten Konawe Selatan menunjukkan nilai minus yang artinya penerimaan di Kabupaten Konawe Selatan relatif lebih rendah dibandingkan di Kabupaten Lombok Timur dengan selisih minus Rp 5 juta.

Besarnya biaya faktor produksi seperti upah tenaga kerja di Kabupaten Konawe Selatan sedikit lebih murah dibandingkan di Kabupaten Lombok Timur dengan selisih sebesar Rp 241.393. Akan tetapi, biaya input produksi seperti harga bibit di Kabupaten Konawe Selatan relatif lebih tinggi dibandingkan di Kabupaten Lombok Timur dengan selisih mencapai Rp 2,6 juta. Tingginya biaya faktor produksi tersebut menyebabkan keuntungan usaha budidaya rumput laut di Kabupaten Konawe Selatan lebih rendah dibandingkan Kabupaten Lombok Timur dengan selisih mencapai minus Rp 7,5 juta.
Melalui Tabel 6 juga dapat dilihat tingkat daya saing komoditas rumput laut Kabupaten Konawe Selatan yang dibandingkan dengan Kabupaten Lombok Timur. Tingkat daya saing tersebut diukur melalui nilai Domestic Resources Cost Ratio (DRCR), Tradables Resources Cost Ratio (TRCR) dan Total Cost Ratio (TCR). Nilai DRCR komoditas rumput laut Kabupaten Konawe Selatan menunjukkan nilai yang lebih kecil dari 1 yang berarti bahwa untuk menghasilkan satu satuan nilai tambah diperlukan kurang dari satu satuan biaya faktor domestik yang kesemuanya dinilai dengan harga-harga bayangan. Nilai DRCR yang sebesar 0,98 berarti bahwa dalam menghasilkan Rp 1 hanya diperlukan Rp 0,98 sumber daya domestik. Dengan demikian, dapat dikatakan bahwa rumput laut di Kabupaten Konawe Selatan lebih memiliki keunggulan komparatif dan lebih berdaya saing dibandingkan usaha budidaya rumput laut di Kabupaten Lombok Timur.

Hal ini menunjukkan bahwa sumber daya domestik yang tersedia di Kabupaten Konawe Selatan masih lebih murah dibandingkan di Kabupaten Lombok Timur. Hasil sama juga ditunjukkan dalam penelitian Azwir (2012) yang menunjukkan bahwa pemanfaatan faktor-faktor produksi (input) oleh petani rumput laut di Kota Kendari, Sulawesi Tenggara sudah efisien. Adapun faktor

Tabel 6. Policy Analysis Matrix Usaha Budidaya Rumput Laut di Kabupaten Konawe Selatan, 2011.

Table 6. Policy Analysis Matrix of Seaweed Farming in the Regency South Konawe, 2011.

\begin{tabular}{lcrrr}
\hline \multicolumn{1}{c}{ Variabel } & Revenue $(\boldsymbol{R p})$ & Factors $(\boldsymbol{R p})$ & \multicolumn{1}{c}{ Tradables (Rp) } & \multicolumn{1}{c}{ Profit (Rp) } \\
\hline Private & $29,150,451$ & $11,046,788$ & $9,715,909$ & $8,387,753$ \\
Social & $34,202,436$ & $11,288,181$ & $7,035,249$ & $15,879,006$ \\
Divergence & $(5,051,985)$ & $(241,393)$ & $2,680,661$ & $(7,491,252)$ \\
\hline DRCR & 0.98 & & & \\
TRCR & 1.38 & & & \\
TCR & 1.13 & & & \\
\hline
\end{tabular}

Sumber: Data Primer (2011)/Source: Primary Data (2011) 
produksi yang paling dominan dan berpengaruh dalam usaha budidaya rumput laut terdiri dari tenaga kerja upahan dan nilai penyusutan (depresiasi) dari aset produksi budidaya rumput laut.

Namun jika dilihat dari nilai TRCR, daya saing rumput laut Kabupaten Konawe Selatan cenderung lebih rendah dibandingkan dengan rumput laut Kabupaten Lombok Timur. Hal ini mengindikasikan bahwa harga satuan tradables input untuk budidaya rumput laut dengan metode longline yang terdiri dari bibit rumput laut dan bahan bakar minyak (BBM) di Kabupaten Konawe Selatan masih lebih mahal dibandingkan di Kabupaten Lombok Timur. Kondisi ini disebabkan oleh tingkat harga rata-rata bibit rumput laut jenis $E$. cottoni sebesar Rp 2.500 dan harga rata-rata BBM mencapai Rp 6.000 di tingkat pembudidaya ketika pengambilan data praktek budidaya di Kabupaten Konawe Selatan pada bulan September 2011.

Tabel 6 juga menunjukkan nilai total cost ratio yang lebih dari 1 , yaitu sebesar 1,38. Nilai total cost ratio diperoleh dari dua variabel rasio, yaitu Domestic Resources Cost Ratio (DRCR) dan Tradables Resources Cost Ratio (TRCR). Hal ini mengindikasikan bahwa usaha budidaya rumput laut Kabupaten Konawe Selatan kurang mampu bersaing dengan rumput laut di Kabupaten Lombok Timur.

Untuk meningkatkan daya saing komoditas rumput laut di Kabupaten Konawe Selatan tersebut, perlu dilakukan efisiensi terhadap biaya produksi. Upaya ini memerlukan intervensi dari pemerintah melalui kebijakannya terkait harga bibit dan harga BBM yang memiliki porsi sangat besar dalam komponen biaya produksi budidaya rumput laut. Berdasarkan perhitungan PAM, daya saing usaha budidaya rumput laut di Kabupaten Konawe Selatan dapat ditingkatkan dengan menurunkan harga satuan di tradables input meliputi bibit dan BBM secara bersamasama sebesar $28 \%$. Namun sebaliknya, perlu diambil tindakan menaikkan harga satuan factor input meliputi tenaga kerja upahan dan depresiasi aset produksi secara bersamasama sebesar $4 \%$.

Tabel 6 juga menunjukkan bahwa usaha budidaya rumput laut di Kabupaten Konawe Selatan mampu membukukan keuntungan privat atau memperoleh keuntungan di atas normal karena penerimaan pembudidaya rumput laut tercatat lebih besar daripada pengeluaran terhadap biaya input tradable dan nontradable (faktor domestik) atau memperoleh keuntungan di atas normal.

Dengan menggunakan matriks PAM, dapat pula diketahui titik impas (break event point - BEP) budidaya rumput laut di Kabupaten Konawe Selatan. Analisis yang digunakan adalah analisis break event point (BEP). Analisis break event point dilakukan untuk mengetahui tingkat produksi dimana tidak ada keuntungan dan tidak ada kerugian. Analisis ini menunjukkan hubungan penjualan, biaya dan keuntungan. Pada penelitian ini, break event point menggunakan pendekatan seberapa besar penggunaan lahan yang dikelola dan seberapa besar tingkat harga yang diterima. Analisis break event point usaha budidaya rumput laut dapat dilihat pada Tabel 7.

Tabel 7. Titik Impas Budidaya Rumput Laut di Kabupaten Konawe Selatan, 2011. Table 7. Break Even Point of Seaweed Farming in the Regency of South Konawe, 2011.

\begin{tabular}{lccc}
\hline Variabel/Variable & Satuan/Unit & Titik Impas/ Break Event Point & Rataan/ Average \\
\hline Luasan/Area & $\mathrm{m}^{2} / \mathrm{m}^{2}$ & 1,085 & 12,589 \\
Harga/Price & $\mathrm{Rp} / I D R$ & 2,121 & 6,818 \\
\hline
\end{tabular}

Sumber: Data Primer (2011)/Source: Primary Data (2011) 
Berdasarkan perhitungan yang dilakukan, kondisi titik impas (BEP) bagi pembudidaya di Kabupaten Konawe Selatan dapat dicapai jika penggunaan lahan yang digunakan minimal seluas $1.085 \mathrm{~m}^{2}$ atau turun 91\% dari rata-rata penggunaan lahan pada saat penelitian dilakukan. Di samping itu, tingkat harga jual yang dapat diterima oleh para pembudidaya rumput laut sebesar Rp 2.121 atau turun sebesar $69 \%$.

Meskipun pembudidaya rumput laut di Kabupaten Konawe Selatan mampu meraih keuntungan di atas normal,tetapi besarnya keuntungan tersebut masih lebih rendah dibandingkan dengan pembudidaya rumput laut di Kabupaten Lombok Timur. Rendahnya penerimaan dan keuntungan yang diterima pembudidaya tersebut paling dominan disebabkan oleh besarnya biaya input usaha yang harus dikeluarkan pembudidaya rumput laut di Kabupaten Konawe Selatan.

Berdasarkan hasil perhitungan dengan PAM, penerimaan pembudidaya Kabupaten Konawe Selatan lebih rendah $15 \%$ dibandingkan penerimaan pembudidaya Kabupaten Lombok Timur. Kesenjangan yang paling mencolok tampak pada tingkat keuntungan rata rata pembudidaya Kabupaten Konawe Selatan yang hampir setengahnya (47\%) dari keuntungan yang mampu dihasilkan pembudidaya di Kabupaten Lombok Timur.

\section{KESIMPULAN DAN IMPLIKASI KEBIJAKAN}

\section{Kesimpulan}

Usaha budidaya rumput laut di
Kabupaten Konawe Selatan dapat
dikatakan lebih memiliki keunggulan
komparatif dan lebih berdaya saing
dibandingkan dengan usaha budidaya
rumput laut di Kabupaten Lombok Timur
jika diukur dari nilai DRCR. Nilai DRCR
tercatat lebih kecil dari 1, yaitu sebesar
0,98 yang artinya untuk menghasilkan
Rp 1 hanya memerlukan sumber daya
domestik sebesar Rp 0,98 .

Namun jika dilihat dari nilai TRCR, usaha budidaya rumput laut di Kabupaten Konawe Selatan kurang mampu bersaing dengan usaha budidaya rumput laut di Kabupaten Lombok Timur. Nilai TRCR yang lebih dari satu, yaitu sebesar 1,38 memiliki arti bahwa untuk menghasilkan $\mathrm{Rp} \mathrm{1,}$ pembudidaya harus mengeluarkan biaya input tradable $\mathrm{Rp} 1,38$. Dengan kata lain, usaha budidaya rumput laut tidak efisien dalam memanfaatkan sumber daya domestik.

\section{Implikasi Kebijakan}

Untuk meningkatkan daya saing pada usaha budidaya rumput laut di Kabupaten Konawe Selatan, perlu dilakukan:

1. kebijakan untuk menurunkan harga satuan di tradables input meliputi bibit dan BBM secara bersama-sama sebesar $28 \%$;

2. kebijakan menaikkan harga satuan factor input meliputi tenaga kerja upahan dan depresiasi aset produksi secara bersamasama sebesar $4 \%$.

\section{DAFTAR PUSTAKA}

Anggadiredja, J.T., Zatnika, A., Purwoto, H. dan S. Istini. 2006. Seri Agribisnis; Rumput Laut. Jakarta: Penebar Swadaya.

Azwir. 2012. Analisis Finansial dan Efisiensi Produksi Usahatani Rumput Laut di Kota Kendari Sulawesi Tenggara. [Tesis, tidak diterbitkan]. Yogyakarta: Universitas Gadjah Mada.

Bank Indonesia. 2009. Budidaya Rumput Laut (Metode Tali Letak Dasar). Jakarta: Direktorat Kredit, BPR, dan UMKM. Jakarta: Bank Indonesia.

Dinas Kelautan dan Perikanan Kabupaten Lombok Timur. 2010. Perkembangan Budidaya Rumput Laut Kabupaten Lombok Timur. Nusa Tenggara Barat: Dinas Kelautan dan Perikanan Kabupaten Lombok Timur. 
DKP. 2008. Statistik Perikanan Indonesia 2008. Jakarta: Departemen Kelautan dan Perikanan RI.

Hasibuan, A.M. dan Bedy S. 2008. Daya Saing Usahatani Lada di Lampung dalam Buletin RISTRI Vol. 1 (1) 2008.

Kementerian Kelautan dan Perikanan. 2010. Statistik Ekspor Hasil Perikanan 2009. Jakarta: Kementerian Kelautan dan Perikanan.

Kementerian Kelautan dan Perikanan. 2011. Statistik Perikanan Budidaya Indonesia 2010. Jakarta: Kementerian Kelautan dan Perikanan.

Kompas. 2011. Tren Penghasil Karagenan Meningkat. Artikel dalam http:// bisniskeuangan.kompas.com/ $\mathrm{read} / 2011 / 09 / 08 / 02162994 /$ Tren. Penghasil.Karagenan. Meningkat, diakses tanggal 14 Februari 2012.

Koo, W.W. and Kennedy, P.L. 2005. International Trade and Agriculture. Blackwell Publishing.
Monke, E.A. dan S.R. Pearson. 1989. Policy Analysis Matrix for Agricultural Development. Ithaca, London: Cornell University Press.

Rajagukguk, M.M. 2009. Analisis Daya Rumput Laut Indonesia di Pasar Internasional. [Skripsi, Tidak Diterbitkan]. Departemen Agribisnis. Fakultas Ekonomi dan Manajemen. Bogor: Institut Pertanian Bogor.

Tempo Interaktif. 2012. Rumput Laut + Bakteri E. Coli = Bahan Bakar Mobil dalam http://rumputlaut.org/?p=93, diakses tanggal 31 Januari 2012.

Wisnu, R. dan Diana R. 2005. Analisa Komposisi Nutrisi Rumput Laut (Euchema Cotoni) Di Pulau Karimunjawa Dengan Proses Pengeringan Berbeda. [Laporan Akhir Kegiatan, Tidak Diterbitkan). Semarang: Universitas Diponegoro. 